\title{
Bimbingan dan Pendampingan Penyelenggaraan Event Untuk UMKM Kopi Sawah
}

\author{
Becik Gati Anjari ${ }^{1}$, Erlangga Andi Sukma ${ }^{2}$, Izzatul Ulya ${ }^{3}$, Eko Boedhi Santoso ${ }^{4}$, Rizka Rahmawati ${ }^{5}$ \\ 1,2,3,4,5 Jurusan Administrasi Niaga, Politeknik Negeri Malang \\ e-mail: ${ }^{1}$ becik.gati@polinema.ac.id, ${ }^{2}$ erlangga.andis@gmail.com, ${ }^{3}$ Izza.ulya91@gmail.com, \\ 4ekoboedhisantoso63@gmail.com,5rizka3rahma@gmail.com,
}

\begin{abstract}
Abstrak
Event merupakan kegiatan rutin yang sering diadakan baik perorangan seperti hajatan perkawinan, maupun perusahaan seperti konferensi dan juga pemilik kafe seperti mengadakan live music untuk menarik pelanggan. Namun keberadaan pandemi Covid-19 sangat mempengaruhi intensitas penyelenggaraan event karena ada banyak peraturan terkait protokol kesehatan yang harus dipatuhi oleh penyelenggara. Oleh sebab itu, maka PPM ini dilaksanakan untuk memberikan jalan tengah kepada pengusaha dalam hal ini adalah Kedai Kopi Sawah, agar tetap dapat mengadakan event namun bisa mengikuti protokol kesehatan yang berlaku. Dengan kerjasama dan partisipasi pemilik Kedai Kopi Sawah, kegiatan pengabdian masyarakat ini dilaksanakan dengan melakukan pemetaan event apa saja yang sering diselenggarakan dan masalah yang dihadapi. Setelah itu akan dilanjutkan dengan penyuluhan, diskusi dan pendampingan. Dari keseluruhan rangkaian kegiatan pengabdian ini, pemilik kedai mendapatkan manfaat dan bantuan dari program bimbingan dan pendampingan terhadap pelaksanaan event di masa pandemi yang sesuai dengan kebutuhan untuk tetap bertahan dan bahkan mengembangkan kegiatan usahanya.
\end{abstract}

Kata kunci: event, pandemi Covid-19, protokol kesehatan

\section{PENDAHULUAN}

Sebagai kota yang memiliki Sumber Daya Manusia yang inovatif sebagai modal pembangunan ekonomi, Kota Malang merupakan kota yang berdaya saing yang kuat. Tidak hanya dikenal dengan kota pendidikan dan pariwisatanya, Malang juga terkenal dengan berbagai sajian kuliner yang beragam. Di kota ini terdapat banyak destinasi kuliner yang menarik terutama kedai kopi. Menurut Kementerian Pertanian, tingkat konsumsi kopi masyarakat Indonesia sekitar 250 ribu ton atau meningkat sebesar 10,54\% menjadi 276 ribu ton pada tahun 2016. Diperkirakan dari tahun 2016 hingga 2021 konsumsi kopi di Indonesia rata-rata akan meningkat 8,22\% setiap tahunnya [1].

Salah satu kedai kopi yang cukup digemari anak muda di kota Malang adalah Kopi Sawah. Kopi Sawah adalah sebuah kedai kopi yang terletak di daerah Sudimoro, didirikan oleh Angga pada 17 Februari 2017, saat masih berstatus mahasiswa Politeknik Negeri di Malang. Semakin maraknya bisnis kedai kopi di daerah Sudimoro membuat persaingan antara satu kafe dengan kafe yang lain menjadi sangat penting. Kopi Sawah mempunyai target konsumen anak muda, dimana 'nongkrong' merupakan salah satu budaya yang ada dan sangat digemari oleh anak-anak muda saat ini. Selain harga yang murah, Kopi Sawah juga mempunyai agenda rutin untuk live music dimana ini juga menjadi salah satu cara promosi untuk mendapatkan pelanggan.

Pada pertengahan tahun 2020 bisnis Kafe Sawah mengalami perubahan drastis akibat pandemi Covid-19 yang terjadi di Indonesia. Hal ini terjadi karena kafe sebagai tempat berkumpul, bercengkrama bahkan bekerja menjadi sepi dengan adanya aturan social distancing dan berbagai protokoler kesehatan. Membangkitkan bisnis kedai kopi di tengah kekhawatiran masyarakat akan penularan virus Covid-19 yang semakin tinggi, menjadi pekerjaan yang tidak mudah. Para pelaku bisnis tidak hanya dituntut untuk memikirkan strategi pemasaran yang tepat serta efektif, tapi juga meyakinkan konsumen bahwa tempat kafe tersebut benar-benar terbebas dari Covid-19. Untuk menghindari kerugian yang semakin besar inovasi dan strategi pemasaran harus dirancang dengan 
matang. Inilah yang menjadi fokus strategi Angga sebagai pemilik Kafe Sawah agar bisnis tetap berjalan.

Oleh sebab itu pemilik kafe sawah membutuhkan bimbingan dan pendampingan pengelolaan penyelenggaraan event agar tujuan penyelenggaraan event dapat berjalan sesuai harapan berdasarkan situasi dan kondisi saat ini.

\section{METODE}

PPM dilaksanakan dengan metode partisipatif, yaitu suatu metode yang melibatkan pelaku pengabdian untuk berperan serta secara langsung pada kegiatan yang dilakukan oleh khalayak sasaran [2]. Metode ini dipilih untuk mendapatkan gambaran dan identifikasi yang jelas, sehingga dengan mudah ditemukan permasalahan dari mitra dan selanjutnya dapat ditentukan pilihan solusi yang tepat. Berikut beberapa metode partisipatif yang dilakukan, sesuai dengan permasalahan yang telah disampaikan sebelumnya:

1. Penyuluhan, agar mitra dapat memahami pentingnya management event sebagai acuan untuk menjalankan sebuah kegiatan sehingga kegiatan tersebut dapat berjalan sistematis, terencana, terstruktur, dan terkontrol, mengingat banyaknya resiko yang akan dihadapi di era pandemi ini.

2. Diskusi, sebagai kegiatan tindak lanjut dari penyuluhan, yaitu memberikan waktu kepada mitra untuk bertanya, berkeluh kesah, menyampaikan pendapat untuk selanjutnya diberikan saran dan masukan serta solusi atas permasalahan yang dihadapi mitra.

3. Pendampingan, setelah dilakukan pengarahan dan diskusi bersama, akhirnya ditemukan langkahlangkah yang dilakukan untuk memecahkan masalah.

4. Evaluasi, dilakukan evaluasi atas pelaksanaan kegiatan PPM apakah telah tepat sasaran dan mampu memberikan solusi kepada mitra, dengan cara memberikan kuesioner kepuasan kepada mitra.

Berikut disampaikan metode pelaksanaan, instrumen dan keberlanjutan program PPM ini:

Tabel 1 metode pelaksanaan dan indikator keberhasilan

\begin{tabular}{|l|lll|}
\hline $\begin{array}{c}\text { Metode } \\
\text { Pelaksanaan }\end{array}$ & \multicolumn{2}{|c|}{ Indikator Keberhasilan } \\
\hline Penyuluhan & 1. Mitra paham pentingnya \\
\hline
\end{tabular}

\begin{tabular}{|c|c|}
\hline $\begin{array}{c}\text { Metode } \\
\text { Pelaksanaan }\end{array}$ & Indikator Keberhasilan \\
\hline & $\begin{array}{l}\text { kegiatan management event } \\
\text { untuk mengurangi resiko } \\
\text { kegagalan di masa pandemi } \\
\text { 2. Mitra paham akan pentingnya } \\
\text { dokumen-dokumen apa saja } \\
\text { yang harus disiapkan dalam } \\
\text { perencanaan event }\end{array}$ \\
\hline Diskusi & $\begin{array}{l}\text { 1. Pelaksana PPM mendapatkan } \\
\text { data untuk diolah menjadi } \\
\text { informasi sebagai dasar } \\
\text { untuk mendapatkan solusi. } \\
\text { 2. Mitra bebas menyampaikan } \\
\text { segala permasalahan dan } \\
\text { mendapatkan saran dan } \\
\text { masukan terkait dengan } \\
\text { bisnis UKM, terutama } \\
\text { bagaimana untuk dapat tetap } \\
\text { survive. }\end{array}$ \\
\hline \multirow[t]{3}{*}{ Pendampingan } & $\begin{array}{l}\text { Mitra mengerti cara } \\
\text { melakukan survei terkait } \\
\text { event serupa. }\end{array}$ \\
\hline & $\begin{array}{l}\text { 2. Mitra dapat membuat } \\
\text { rencana detail terkait } \\
\text { keuangan, operasional dan } \\
\text { promosi }\end{array}$ \\
\hline & $\begin{array}{l}\text { 3. Mitra dapat membuat } \\
\text { kerangka acuan kerja } \\
\text { (why,when, who, where dan } \\
\text { what) terkait rencana } \\
\text { penyelenggaraan event pada } \\
\text { kafe sawah }\end{array}$ \\
\hline Evaluasi & $\begin{array}{l}\text { Mitra menyatakan puas atas } \\
\text { penyelenggaraan kegiatan PPM }\end{array}$ \\
\hline
\end{tabular}

\section{HASIL DAN PEMBAHASAN}

\subsection{Tahap Penyuluhan}

Pada tahap ini mitra diberikan pemahaman terkait pentingnya kegiatan management event untuk mengurangi resiko kegagalan di masa pandemi dengan terlebih dahulu mempelajari studi kasus. Ada baiknya jika perencanaan tidak hanya satu, namun ada rencana cadangan (Plan A dan Plan B), yang bertujuan untuk mengantisipasi segala kondisi dan situasi yang tak terduga. Misalnya karena faktor alam, kebijakan pemerintah, human error, dan ketidakpastian yang lain. Berikut beberapa event yang gagal/ditunda penyelenggaraannya karena 
beberapa sebab serta event yang dapat segera berubah strategi menyesuaikan dengan kondisi:

1. Ditunda penyelenggaraannya karena Pandemi Covid-19

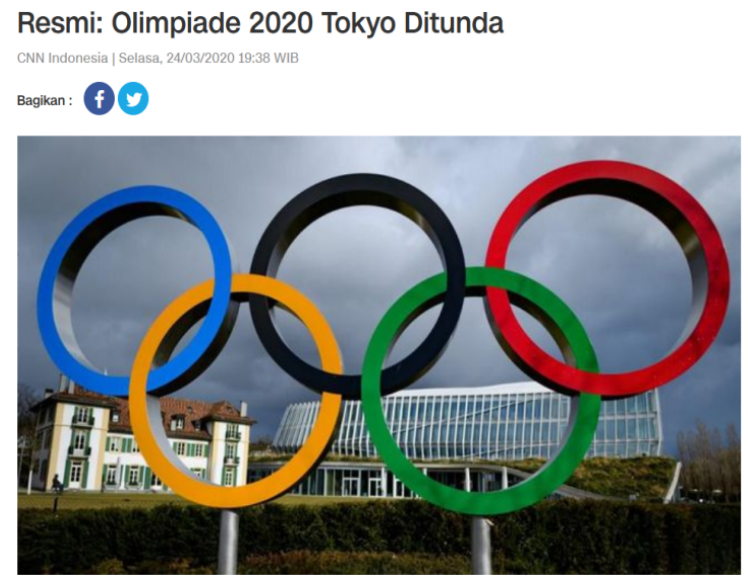

Gambar 1 Olimpiade 2020

2. Dibatalkan penyelenggaraannya karena tim penyelenggara belum mendapatkan ijin.

Tak Dapat Ijin, Acara Perpustakaan Jalanan Tabanan Dibatalkan

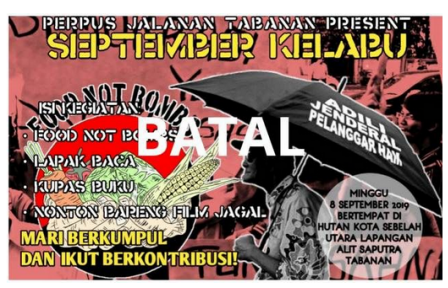

Gambar 2 Perpustakaan Jalanan

3. Event yang diselenggarakan menggunakan rencana kedua, setelah rencana awal gagal dilaksanakan

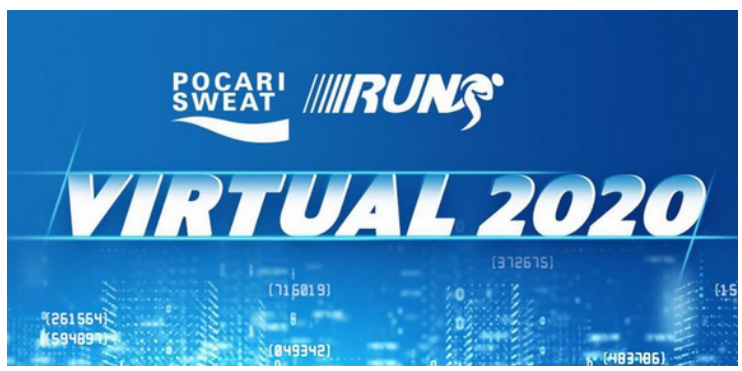

Gambar 3 E-run Pocari Sweat

Selanjutnya Mitra diberikan penjelasan terkait dokumen yang harus disiapkan dalam mengelola event dengan memberikan media modul pendamping praktik management event dan panduan pelaksanaan, kebersihan, kesehatan, keselamatan dan kelestarian lingkungan di penyelenggaraan kegiatan (Event).

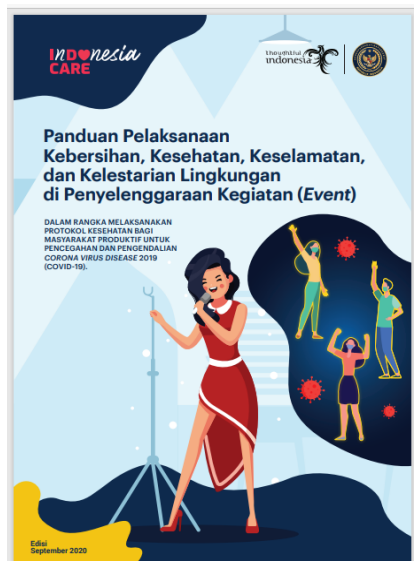

Gambar 4 Buku panduan pelaksanaan event selama pandemi

\subsection{Tahap Diskusi}

Pada tahap ini mitra menjelaskan daya tarik pada kafe yang dibangun dan kendala-kendala yang dihadapi selama pandemi. Dari hasil diskusi di dapatkan informasi dari beberapa aspek yaitu manajemen, produksi dan permasalahan yang dialami mitra. Selanjutnya akan diberikan gambaran solusi yang dapat di ambil yang terjabar sebagai berikut :

\subsubsection{Aspek Manajemen}

Sistem manajemen di Kopi Sawah masih bersifat sederhana, tidak menggunakan dasar teori tertentu yang mana membuat operasionalnya menjadi sangat sederhana. Dengan jumlah pegawai yang sedikit, dan menggunakan sistem shif membuat pengaturan karyawan oleh pemilik menjadi mudah dilakukan. Fokus dari sistem manajemen di Kopi Sawah bertujuan untuk mempertahankan pelanggan dan menambah jumlah pelanggan, sehingga dengan adanya event yang diadakan secara terjadwal dapat membantu menambah jumlah pelanggan untuk ke depannya.

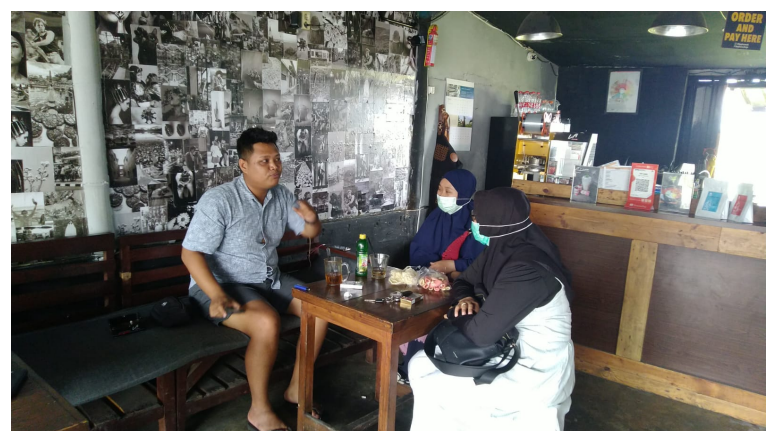

Gambar 5 Diskusi awal 


\subsubsection{Aspek Produksi}

Produksi di Kopi Sawah sangat tergantung pada jumlah pelanggan yang datang untuk menikmati kopi di tempat ini. Rasa yang konsisten karena menggunakan SOP yang jelas dan juga ke-khas-an rasa juga merupakan sesuatu yang dipertahankan di Kopi Sawah. Semua barista dan pegawai yang bertanggung jawab menyiapkan pesanan dilatih sendiri oleh pemilik, yang mana nantinya para barista dan pegawai dapur yang terlatih dapat secara berkelanjutan melatih pegawai baru yang dipekerjakan di Kopi Sawah. Dengan adanya pandemi ini, maka produksi yang dihasilkan pun mengalami penurunan sampai $50 \%$.

\subsubsection{Permasalahan Mitra}

Masalah yang diangkat pada kegiatan PPM ini adalah bagaimana Event Live Music yang selama ini menjadi andalan Kopi Sawah bisa dilaksanakan kembali dengan aman dimasa pandemi dengan management event yang baik, karena dengan keterbatasan dan situasi saat ini pemilik juga mengalami kebingungan untuk menyelenggarakan event yang aman dan tidak melanggar aturan yang ada. Dalam perencanaan terdapat banyak hal yang kompleks, banyak kebutuhan di luar dugaan. Seringkali pelaksanaan sebuah event, sulit dilaksanakan seratus persen sama dengan yang direncanakan. Namun perencanaan tetap perlu untuk meminimalisir ketidaksesuaian, serta menjadi pedoman langkah-langkah yang harus dilakukan. Meskipun tidak sama seratus persen, perencanaan dilakukan intinya yaitu "tidak gagal pada saat event berlangsung”. Pemilik kafe sawah sadar betul bahwa untuk membuat sebuah event harus direncanakan secara matang. Oleh sebab itu pemilik kafe sawah membutuhkan bimbingan dan pendampingan pengelolaan penyelenggaraan event agar tujuan penyelenggaraan event dapat berjalan sesuai harapan.

Berdasarkan identifikasi masalah di atas, maka beberapa solusi yang dilakukan adalah pendampingan dan pembimbingan terkait management event. Dalam PPM ini Kami menggunakan prinsip POAC [3], yang terdiri dari Planning, Organizing, Actuating dan Controlling sebagai tahapan dalam proses manajemen. Gambar 6 di bawah ini menggambarkan tentang siklus POAC.

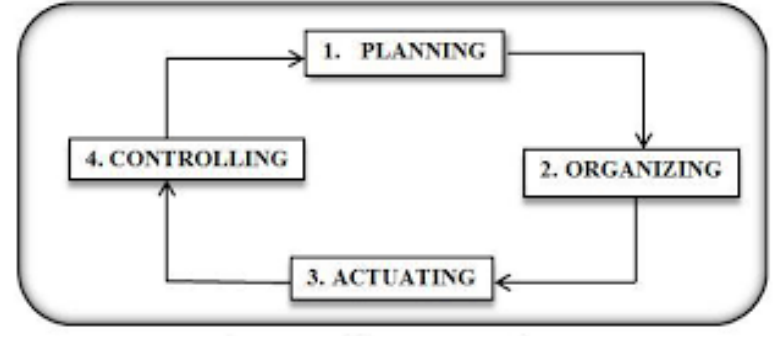

Gambar 6 Siklus POAC

Siklus POAC di atas terdiri dari 4 (empat) tahapan, yang masing-masing dapat dijabarkan sebagai berikut:

a. Planning, pada tahap ini dimulai dengan mencari cara bagaimana mencapai tujuan dan pengumpulan informasi. Misalnya mencari informasi tentang event sejenis yang telah dilakukan oleh pihak lain sebelumnya. Dipelajari beberapa hal seperti pihak-pihak yang terlibat, tempat yang digunakan, jadwal penyelenggaraan event, biaya dan sumber dana yang diperoleh.

b. Organizing, pada tahap ini diadakan pembagian tugas-tugas pada orang yang terlibat dalam aktivitas event tersebut, sesuai dengan kompetensi SDM yang dimiliki, dapat dikatakan bahwa kegiatan ini merupakan keseluruhan proses memilih orang-orang serta mengalokasikannya sarana dan prasarana untuk menunjang tugas orangorang itu dalam organisasi. Dengan pembagian tugas tersebut maka pekerjaan menjadi lebih ringan. Disinilah salah satu prinsip manajemen, yaitu membagi tugas sesuai dengan keahliannya.

c. Actuating, pada tahap ini setiap SDM harus bekerja sesuai dengan tugas, fungsi dan peran, keahlian dan kompetensi masingmasing SDM untuk mencapai tujuan penyelenggaraan event.

d. Controlling, pada tahap ini pemilik harus mengetahui bagaimana penyimpanganpenyimpangan yang terjadi. Baik dalam tahap perencanaan, pelaksanaan maupun pengorganisasian. Sehingga dengan hal tersebut dapat segera dilakukan koreksi, antisipasi dan penyesuaian-penyesuaian sesuai dengan situasi dan kondisi yang terjadi sejak dalam perencanaan mengingat di era pandemi akan ada banyak perubahan kebijakan yang membuat gagalnya event. 


\subsection{Tahap Pendampingan}

Pada proses pendampingan mitra melakukan beberapa kegiatan yaitu :

\section{Mitra melakukan survei terkait event serupa}

Dari hasil survey didapatkan beberapa info terkait penyelenggaraan event band seperti beberapa ketentuan menggelar konser musik di Kota Malang saat pandemi Covid-19 misalnya:

a. Alat band tidak boleh dipakai secara bergantian dan diusahakan menggunakan peralatan pribadi,

b. Pemakaian masker bagi penampil boleh dilepas sementara dan digantikan faceshield pada saat perform,

c. Pembatasan aktivitas di keramaian, maksimal 75 persen dari kapasitas total tempat,

d. Jika terdapat temuan pelanggaran, maka pihak Event Organizer (EO) sebagai penyelenggara kegiatan yang harus bertanggung jawab.

2. Mitra membuat rencana detail terkait keuangan, operasional dan promosi

Pada tahap ini mitra diminta untuk melakukan pembagian pembiayaan event Berdasarkan urutan waktu pengeluaran biaya dalam sebuah event terbagi atas:

a. Cost Before Event. Biaya yang dikeluarkan sebelum event dimulai misal: uang muka biaya sewa ruang, biaya promosi, biaya pemasaran, dan sebagainya.

b. Cost During Event. Biaya yang dikeluarkan pada saat berlangsungnya event. Seperti, konsumsi, transportasi, akomodasi, honor pengisi acara, dan sebagainya.

c. Cost After Event. Biaya yang dikeluarkan sesudah event berlangsung umumnya untuk pelunasan, namun juga biaya-biaya yang harus dikeluarkan, seperti: biaya pemberitaan media, penambahan fasilitas dan sebagainya.

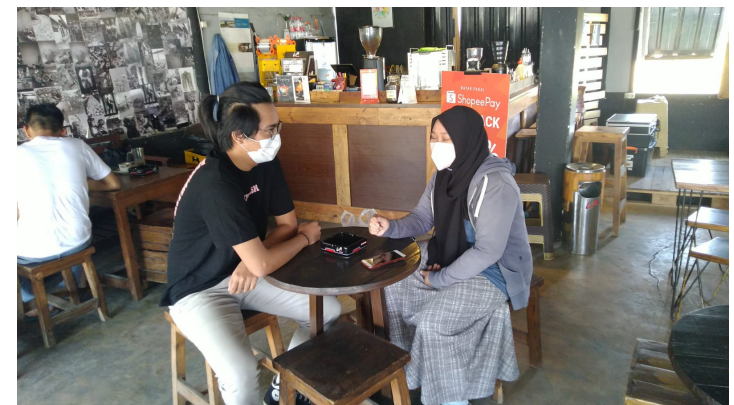

Gambar 7 Diskusi terkait keuangan

3. Mitra dapat membuat kerangka acuan kerja (why, when, who, where dan what) terkait rencana menyelenggaraan event pada kafe sawah.

Pada tahap ini mitra menjelaskan terkait kerangka acuan kerja berdasarkan beberapa point pertanyaan yaitu:

a. Why: Berkaitan dengan tujuan yang akan dicapai dalam acara ini, khususnya dalam memenuhi kebutuhan dan keinginan khalayak.

b. Who: Berkaitan dengan setiap personal yang akan terlibat dalam kegiatan ini, juga berhubungan dengan target sasaran, kelompok usia, jenis kelamin, pendidikan dan gaya hidup.

c. Where: Berkaitan dengan tempat penyelenggaraan acara yang paling tepat untuk khalayak sasaran, hal ini memiliki pengaruh pada atmosfir suasana pertunjukkan yang akan digelar untuk mempengaruhi emosi penonton.

d. When: Berkaitan dengan waktu yang paling tepat untuk penyelengaraan acara dan juga mempertimbangkan adanya fleksibilitas atau kelonggaran yang dihubungkan dengan waktu untuk penelitian dan persiapan.

e. What: Berkaitan dengan bagaimana mengemas event ini agar menarik bagi khalayak sasaran, terdiri dari nama atau jenis acara, isi program dan elemen yang dibutuhkan. 


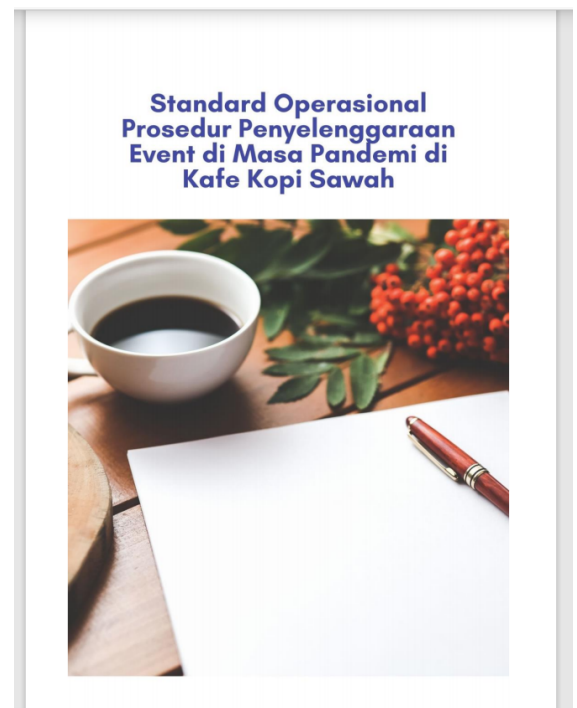

Gambar 8 Hasil Pendampingan

\subsection{Evaluasi}

Setelah pelaksaanaan bimbingan dan pendampingan kepada UMKM Kopi Sawah pemilik menyatakan puas karena materi yang diberikan relevan dalam mengurangi resiko penyelenggaraan event dimasa pandemi. Selain itu materi ini sangat berguna untuk mengantisipasi kondisi di masa pandemi yang berhubungan efesiensi keuangan, pelaksanaan, kebersihan, kesehatan, keselamatan dan kelestarian lingkungan penyelenggaraan kegiatan serta mudah diterima, dimengerti dan bersifat praktis.

\section{KESIMPULAN}

Kegiatan Pengabdian Pada Masyarakat (PPM) dalam bentuk bimbingan dan pendampingan pengelolaan penyelenggaraan event untuk UMKM kopi sawah telah dilaksanakan dengan lancar. Pembimbingan ini menggunakan prinsip POAC (Planning, Organizing, Actuating dan Controlling). Metode tersebut dirasa efektif digunakan dalam pendampingan dibuktikan dengan hasil survei kepuasan mitra yang menunjukan bahwa $83 \%$ mitra merasa puas terkait metode yang digunakan dalam pendampingan, pemberian solusi permasalahan, keaktifan tim pendamping, frekuensi pendampingan serta peningkatan kemandirian, dan peningkatan ilmu pengetahuan.

Mitra memberikan respon yang positif selama pembimbingan berlangsung. Materi yang diberikan mudah dipahami dan sangat berguna dalam melaksanakan live music selama pandemi. Selain itu, mitra juga berharap adanya bimbingan dan pendampingan lain untuk meningkatkan minat pengunjung dengan tetap menjalankan protokoler kesehatan.

\section{SARAN}

Saran diberikan kepada mitra yaitu kopi sawah dan Jurusan Administrasi Niaga Politeknik Negeri Malang. Saran untuk Mitra, agar tetap melakukan perencanaan yang baik dan terorganisir dalam melakukan event selanjutnya, dengan demikian Mitra akan terbiasa menerapkan materi yang telah didapat.

Saran untuk Jurusan Administrasi Niaga, untuk kegiatan pengabdian selanjutnya bisa memperluas mitra UMKM.

\section{UCAPAN TERIMA KASIH}

Penulis mengucapkan terima kasih kepada Politeknik Negeri Malang yang telah memberi dukungan moral dan dana terhadap program pengabdian masyarakat ini. Terima kasih juga untuk Jurusan Administrasi Niaga dan Mitra yang telah memberikan dukungan moral dan membantu jalannya pengabdian ini.

\section{DAFTAR PUSTAKA}

[1] Direktorat Jenderal Perkebunan, 2019, Statistik Perkebunan Indonesia: Kopi 2017-2019, Kementerian Pertanian, Jakarta.

[2] Dwiluthfianti, 2015, Desain Partisipatif pada Taman Lingkungan Permukiman di Pondok Melati, Bekasi, IPB University, Bogor, http://repository.ipb.ac.id/handle/123456789/79 596, diakses tanggal 29 Desember 2020.

[3] Sukarna, 2011, Dasar-dasar Manajemen, Mandar Maju, Bandung. 